\title{
Reconstruction finite element model of cars
}

\author{
Hung Anh Ly ${ }^{1,2, *}$, Phu Thuong Luu Nguyen ${ }^{3}$, Dinh Nhat Tran ${ }^{1,2}$, Thien Phu Nguyen ${ }^{1,2}$
}

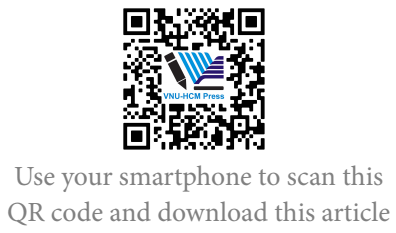

${ }^{1}$ Aerospace Engineering Department, $\mathrm{Ho}$ Chi Minh City University of Technology

${ }^{2}$ Viet Nam National University Ho Chi Minh City

${ }^{3}$ Department of Automotive Engineering Institute of Engineering, Ho Chi Minh City University of Technology

(HUTECH)

\section{Correspondence}

Hung Anh Ly, Aerospace Engineering Department, Ho Chi Minh City

University of Technology

Viet Nam National University Ho Chi Minh City

Email: lyhunganh@hcmut.edu.vn

History

- Received: 27-10-2020

- Accepted: 03-3-2021

- Published: 15-3-2021

DOI : 10.32508/stdjet.v4i1.782

\section{Check for updates}

\section{Copyright}

(c) VNU-HCM Press. This is an openaccess article distributed under the terms of the Creative Commons Attribution 4.0 International license.

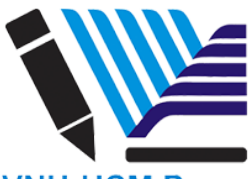

ABSTRACT

The experimental method used in a frontal crash of cars costs much time and expense. Therefore, numerical simulation in crashworthiness is widely applied in the world. The completed car models contain a lot of parts which provided complicated structure, especially the rear of car models do not contribute to behavior of frontal crash which usually evaluates injuries of pedestrian or motorcyclist. In order to save time and resources, a simplification of the car models for research simulations is essential with the goal of reducing approximately $50 \%$ of car model elements and nodes. This study aims to construct the finite element models of front structures of vehicle based on the original finite element models. Those new car models must be maintained important values such as mass and center of gravity position. By using condition boundaries, inertia moment is kept unchanged on new model. The original car models, which are provided by the National Crash Analysis Center (NCAC), validated by using results from experimental crash tests. The modified (simplistic) vehicle FE models are validated by comparing simulation results with experimental data and simulation results of the original vehicle finite element models. LS-Dyna software provides convenient tools and very strong to modify finite element model. There are six car models reconstructed in this research, including 1 Pick-up, 2 SUV and 3 Sedan. Because car models were not the main object to evaluate in a crash, energy and behavior of frontal part have the most important role. As a result, six simplified car models gave reasonable outcomes and reduced significantly the number of nodes and elements. Therefore, the simulation time is also reduced a lot. Simplified car models can be applied to the upcoming frontal simulations.

Key words: Finite element model, internal energy, crashworthiness, simplified vehicle, front end optimization

\section{INTRODUCTION}

The frontal car crash is one of the most well-known tests in the automotive safety industry and the finite element method (FEM) is also widely used to simulate this kind of test. The simulation, or virtual test, is useful not only in fastening the development process but also in helping to reduce expenditure. In this simulation, the numerical model of a vehicle is given an initial velocity to bump into a constrained solid wall. In the frontal car crash test, only the properties of the frontal part of the car are attractive to researchers as the other parts seem to be unaffected by the impact. Therefore, the rear parts of the vehicle can be removed to reduce the overall number of parts and elements, which then results in less time and hardware resources to run the simulation. The modified model, however, must show consistency with the full model in terms of both kinematics and dynamics. According to a study by Mathias Stein et al. ${ }^{1}$, the cars model was assessed at three different energy levels in the form of pedestrian crashes, low and high energy crashes against obstacles and other vehicles. Therefore, three highly parametric simplified models were established to identify the variables with high impact on the self and partner protection, pedestrian safety and insurance classification tests. Finally, the three models can be merged together into on unified parametric car model. In the research by Mathias Stein, SFE CONCEPT was used to reduce unimportant details. Moreover, MATLAB was also used to process output files and LS-Dyna was used to solve calculations. In 2005, Y. $\mathrm{Liu}^{2}$ published a research regarding to developing of simplified model for crashworthiness analysis. This research represented a modified method based on the existing collapse theories but the researcher developed a new collapse theory required to predict the crash behavior for the thin-walled channel section beams. All the theory and modeling method developed in this research are applied for creating simplified models. Both the simplified and detailed models are used for crashworthiness analyses, results show that the errors caused by the simplified models are fewer than $10 \%$ and the simplified models only take less than $10 \%$ of the computer time of the corresponding detailed models. Another research regarding to modify FE vehicle model of $\mathrm{H}$. Al-Thairy and Y.C. 
Wang $^{3}$. The main objective of this study is to present and validate a simplified numerical vehicle model that can be used to simulate the effects of vehicle frontal impact on steel columns by using the commercial finite element code ABAQUS/Explicit. The simplified numerical vehicle model treats the vehicle as a springmass system. The proposed model consists of three parts: an undeformable body representing the total vehicle mass; a spring or connector with nonlinear force-deformation relationship to represent the dynamic stiffness of the vehicle; and a rigid but weightless plate to generate the contact between the springmass system and the impacted column. The dynamic load-deformation characteristic of the spring is assumed to be bilinear: the initial linear elastic part simulating the vehicle deformation until it has reached the vehicle engine box, followed by a near rigid relationship. This concept has been validated by comparison against simulation results of steel columns under different impact velocities, axial load ratios, boundary conditions, and slenderness ratios using the fullscale vehicle model and using the proposed simplified spring-mass model. Having validated the proposed model, this study presents the derivations and validations of an equation to predict the equivalent linear stiffness of the vehicle that can be used either in a future numerical simulation model or in an energy based analytical model. Because of the complexity and time consuming of the previous method, this study will present the reduction method using only LS-Dyna software but still ensure relative accuracy with the original model. To achieve that, the modified model must have the same mass and the same position of center of gravity (C.G). The FEM car models built by The National Crash Analysis Center (NCAC) are complicated. Because of their use for engineering analysis, it is not easy to modify the geometry and topology of vehicle structures. The creation of a new FEM model is all based on flexible tools provided by the LS-DYNA software. The geometrical structure is simplified with a significantly reduced number of elements and parts while still creating constraints among the parts and the added mass to ensure accuracy for the new FEM model. The result is a newly created model that solves the problem of time and resource consumption during research simulation. Thus, the purpose of this paper is to develop the FE models of vehicle front structures based on available FE models of a sedan, a pickup, a neon, a Camry, and an SUV.

\section{METHODOLOGY}

With a large amount of cost and insufficient facilities, the experimental method in Vietnam is minimal.
Hence, the methodology in this project will be based on numerical methods. Furthermore, there is much software on the market that supports numerical computation. In particular, the finite element method, which is a popular, convenient method that saves a lot of time and money.

The software can be mentioned as: ANSYS, ABAQUS, SOLID WORK and LS - DYNA. Among these packages, LS-DYNA is widely used in automobile industry for simulating crash tests, and it provides a large number of dummy models as well as car models that are compatible with LS-DYNA solvers. Therefore, LSDYNA will be the software used in this project.

\section{Constrained Nodal Rigid Body}

Following guideline of FEA Information Inc. Global News \& Industry Information ${ }^{4}$, Constrained Nodal Rigid Bodies (CNRB) are treated internally in LSDYNA like a rigid body part, which uses the MAT_RIGID material model. A set of nodes is defined for each nodal rigid body definition with a minimum number of 2 nodes. Nodal rigid bodies with one node are deleted. The most common usage of the NODAL_RIGID_BODY definition is to model rigid, i.e., non/breakable, connections between structural parts. It is also common practice to model spot welds and others weld types using this definition. The ${ }^{*}$ CONSTRAINED_NODE_SET option in LS-DYNA eliminates all rotational degree-offreedom within the set and should be used cautiously. In this study, the node with added mass is connected to the body by means of Nodal Rigid Body constraints (CNRB). These constraints are also used to hold the rear boundary edge to compensate for their reduction in stiffness.

\section{Finite element car models.}

The finite element (FE) models were developed through the process of reverse engineering at the $\mathrm{Na}$ tional Crash Analysis Center (NCAC) of The George Washington University (GWU). This paper focuses to 06 FEM car models as shown in Fig. 1 including 01 Pickup model (Chevrolet C2500 ${ }^{5}, 02$ SUV car models (Toyota Rav $4^{6}$, Ford Explorer ${ }^{7}$ ) and 03 sedan car models (Yaris ${ }^{8}$, Camry ${ }^{9}$, and Dodge Neon ${ }^{10}$ ). Each vehicle model has been verified with the experimental test. The NCAC provides data for each vehicle model including simulation method and experiment method. This data comes with a complete car model. These detailed FE models were constructed to include full functional capabilities of the suspension and steering subsystems, so the FE models are required 
to have a simplistic method to change up original FE models. In this study, simplistic algorithm is introduced below and it comprises three principal steps:

- Deleting unnecessary parts.

- Conserve volume and position of central

- Adding boundary conditions.

In the following sections, three above steps will be discussed in more detail.

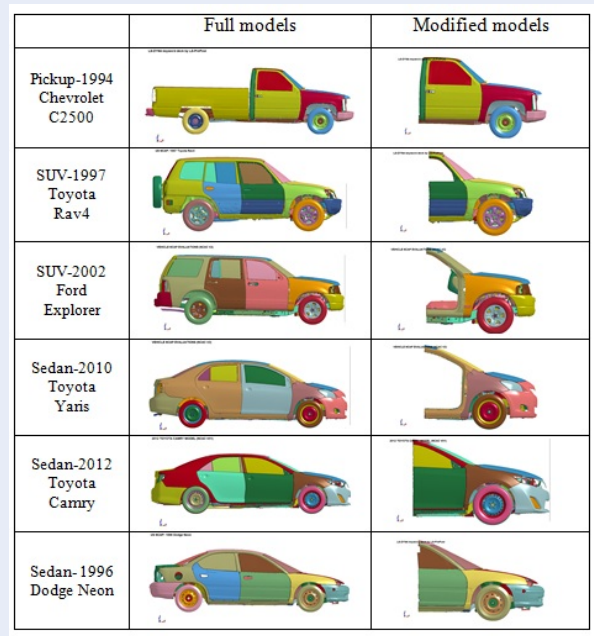

Figure 1: Original vehicle models and modified vehicle models

\section{Deleting unnecessary part.}

Considering the important part of vehicle in crash test simulation, the frontal structure is kept while the rear parts are unnecessary, so they will be deleted. Results after deletion are shown in Modified models part of Fig. 1.

\section{Conserve volume and position of central.}

The mass and the position of central will be change through the deleting process. So, the mass and the position of central need to balance. In other to add extra mass, a node is created and added with extra mass. Furthermore, the modified model's C.G has to the same as the original model's C.G. Therefore, the extra mass is not enough. The coordinates of this node need to be calculated and refined. Finally, a node with added mass is connected to the body by means of Nodal Rigid Body constraints (CNRB).

Here, the formula:

$$
\left(m_{1}-m_{2}\right) x_{n}=m_{1} x_{1}-m_{2} x_{2}
$$

Where $m_{1}, m_{2}$ are the mass of original and modified models while $x_{1}, x_{2}$ are position in the $\mathrm{x}$ direction of original and the modified models, respectively. Repeat those for $y$ and $z$ direction.

\section{Adding boundary conditions.}

Although the mass and position have been preserved, due to the majority loss of the rear parts, a change in moment of inertia occurs. The rear of the car is still affected by external forces, which include gravity and lift at the rear wheels. To ignore the effects of unnecessary parts, some boundary conditions need to be added to the modified model. Position of boundary condition is shown in Fig. 2.

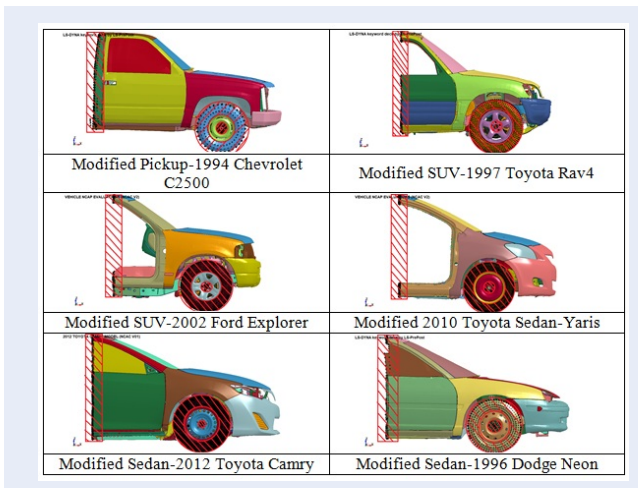

Figure 2: Boundary conditions are added to car models

The boundary conditions are applied to rearmost elements of the new model and the wheel housings which have only one degree of freedom in the direction car move straight. The axis of the wheel has 2 degrees of freedom which are in the straight direction and car's high direction. Thus, the modified model will ensure that there is no external force impacting the back of the vehicle so that the vehicle will be erected. It is noticed that the modified model is used to investigate the behavior of frontal collision. Therefore, energy and momentum of the modified model must be similar to the full models.

\section{Type of element}

Each model is composed of many types of elements. Depending on each part of the model, a different type of element is used. For example, element_mass (3D structural mass element) for mass node while element_shell (three, four, six, and eight node 2D thinshell elements) for windsheld, plate structure...

\section{Simulation set up}

All the modified models in this study are set up to contact with NCAP wall at $56.3 \mathrm{~km} / \mathrm{h}$ as demonstration in Fig. 3. 


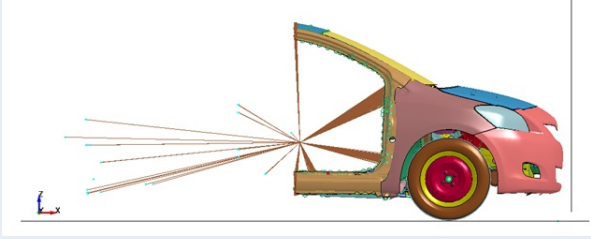

Figure 3: Positioning of Sedan-2010 Toyota Yaris model and NCAP wall.

The simulation problems in the research is all frontal contacts. The CONTACT AUTOMATIC SURFACE TO SURFACE keyword was used between modified car models and NCAP wall. Velocity, acceleration, displacement, force and energy data values are considered.

\section{RESULT AND DISCUSSION}

\section{Validation of mass and position of C.G}

The specification of comparing of original vehicle models and the modified vehicle models is shown below from Table 1 to Table 6.

All of modified models reduce almost $50 \%$ of the total number of nodes and elements except the Pickup model, the mass and location of C.G of modified vehicle models are similar to the original vehicle models.

\section{Verification of modified vehicle models}

The FE models are set to have an initial velocity of $56.3 \mathrm{~km} / \mathrm{h}$ and bump into a rigid wall created by $4 \mathrm{~N}$ Shell element. The simulation results of the full model impacting an analytical wall downloaded from CCSA website is used for benchmarking.

\section{Pickup-1994 Chevrolet C2500}

Deformation of Pickup-1994 Chevrolet C2500 is described typically at $30 \mathrm{~ms}$ and $80 \mathrm{~ms}$ in Figure 4. The velocity of left and right seat crossmember are shown in Figure 5 and Figure 6 . The velocity curve of modified model agrees well with results in ${ }^{5}$.

The acceleration of left and right seat cross member are shown in Figure 7 and Figure 8. There is fluctuation but the tendency of all acceleration curves are similar. In particular, the acceleration curve of Modified model and NCAP Test 1741 show a good result. The rigid body displacement is shown in Figure 9 while the total wall force is represented in Figure 10. The rigid body displacement curve of Modified model is higher than that of Full model from $0.06 \mathrm{~s}$ to $0.15 \mathrm{~s}$. However, the tendency of them are good. The results

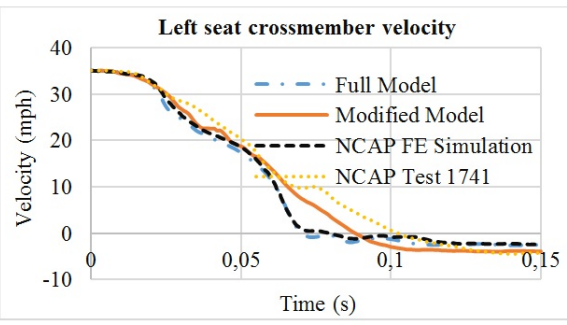

Figure 5: Comparison of left seat crossmember velocity for Pickup-1994 Chevrolet C2500

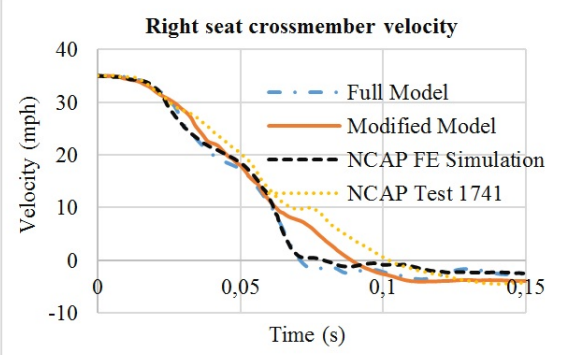

Figure 6: Comparison of right seat crossmember velocity for Pickup-1994 Chevrolet C2500

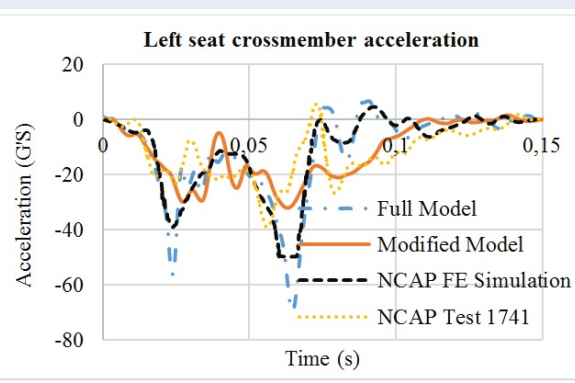

Figure 7: Comparison of left seat cross member acceleration for Pickup-1994 Chevrolet C2500

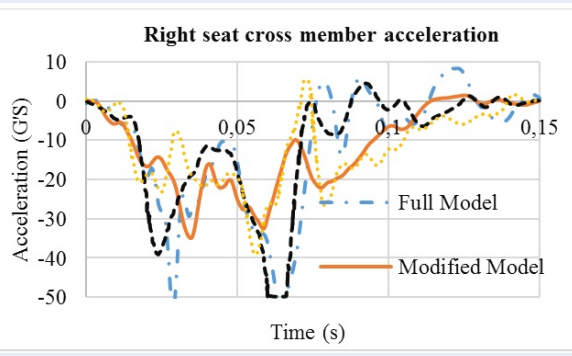

Figure 8: Comparison of right seat cross member acceleration for Pickup-1994 Chevrolet C2500 
Table 1: Comparison between the original and modified Pickup-Chevrolet C2500 model.

\begin{tabular}{|c|c|c|c|c|}
\hline & & Original model (O) & Modified model (M) & Difference $(\mathrm{M} / \mathrm{O})$ \\
\hline Number of nodes & & 66586 & 51519 & $\downarrow 23 \%$ \\
\hline Number of elements & & 58404 & 44537 & $\downarrow 24 \%$ \\
\hline Mass (kg) & & 2013.21 & 2013.21 & $0 \%$ \\
\hline \multirow[t]{3}{*}{ Location of C.G } & $\mathrm{x}$ & 2219.64 & 2219.64 & $0 \%$ \\
\hline & y & -2.90134 & 2.90136 & $0 \%$ \\
\hline & z & 664.751 & 664.751 & $0 \%$ \\
\hline
\end{tabular}

Table 2: Comparison between the original and modified SUV-1997 Toyota Rav4 model.

\begin{tabular}{|c|c|c|c|c|}
\hline & & Original model $(\mathrm{O})$ & Modified model (M) & Difference $(\mathrm{M} / \mathrm{O})$ \\
\hline Number of nodes & & 478624 & 252134 & $\downarrow 47 \%$ \\
\hline Number of elements & & 494127 & 270353 & $\downarrow 45 \%$ \\
\hline Mass (kg) & & 1250.57 & 1250.59 & $0 \%$ \\
\hline \multirow[t]{3}{*}{ Location of C.G } & $\mathrm{x}$ & -1846.59 & -1846.6 & $0 \%$ \\
\hline & $y$ & -19.3392 & -19.3393 & $0 \%$ \\
\hline & $\mathrm{z}$ & 587.338 & 587.337 & $0 \%$ \\
\hline
\end{tabular}

Table 3: Comparison between the original and modified SUV-2002 Ford Explorer model.

\begin{tabular}{|c|c|c|c|c|}
\hline & & Original model $(\mathrm{O})$ & Modified model (M) & Difference $(\mathrm{M} / \mathrm{O})$ \\
\hline Number of nodes & & 724684 & 298830 & $\downarrow 59 \%$ \\
\hline Number of elements & & 714675 & 294690 & $\downarrow 59 \%$ \\
\hline Mass (kg) & & 2244.3 & 2251.8 & $0 \%$ \\
\hline \multirow[t]{3}{*}{ Location of C.G } & $\mathrm{x}$ & -2242.81 & -2248.04 & $0 \%$ \\
\hline & $\mathrm{y}$ & 1.13601 & 1.1602 & $2 \%$ \\
\hline & $\mathrm{z}$ & 633.813 & 622.946 & $2 \%$ \\
\hline
\end{tabular}

Table 4: Comparison between the original and modified Sedan-2010 Toyota Yaris model.

\begin{tabular}{|c|c|c|c|c|}
\hline & & Original model $(\mathrm{O})$ & Modified model (M) & Difference $(\mathrm{M} / \mathrm{O})$ \\
\hline Number of nodes & & 1480516 & 386741 & $\downarrow 23 \%$ \\
\hline Number of elements & & 1514288 & 395772 & $\downarrow 24 \%$ \\
\hline Mass (kg) & & 1253.49 & 1253.49 & $0 \%$ \\
\hline \multirow[t]{3}{*}{ Location of C.G } & $\mathrm{x}$ & -1819.29 & -1819.29 & $0 \%$ \\
\hline & $\mathrm{y}$ & -2.38537 & -2.38537 & $0 \%$ \\
\hline & $\mathrm{z}$ & 538.742 & 538.742 & $0 \%$ \\
\hline
\end{tabular}


Table 5: Comparison between the original and modified Sedan-2012 Toyota Camry model.

\begin{tabular}{|c|c|c|c|c|}
\hline & & Original model $(\mathrm{O})$ & Modified model (M) & Difference $(\mathrm{M} / \mathrm{O})$ \\
\hline Number of nodes & & 1688139 & 793615 & $\downarrow 53 \%$ \\
\hline Number of elements & & 1672877 & 788074 & $\downarrow 53 \%$ \\
\hline Mass (kg) & & 1627.61 & 1627.59 & $0 \%$ \\
\hline \multirow[t]{3}{*}{ Location of C.G } & $\mathrm{x}$ & -1996.85 & -1996.85 & $0 \%$ \\
\hline & $\mathrm{y}$ & 12.3243 & 12.3243 & $0 \%$ \\
\hline & $\mathrm{z}$ & 516.142 & 516.141 & $0 \%$ \\
\hline
\end{tabular}

Table 6: Comparison between the original and modified Sedan-1996 Dodge Neon model.

\begin{tabular}{|c|c|c|c|c|}
\hline & & Original model $(\mathrm{O})$ & Modified model (M) & Difference $(\mathrm{M} / \mathrm{O})$ \\
\hline Number of nodes & & 283909 & 144104 & $\downarrow 49 \%$ \\
\hline Number of elements & & 271147 & 135801 & $\downarrow 50 \%$ \\
\hline Mass (kg) & & 1333.22 & 1333.09 & $0 \%$ \\
\hline \multirow[t]{3}{*}{ Location of C.G } & $\mathrm{x}$ & 2713.13 & 2712.92 & $0 \%$ \\
\hline & y & 142.725 & 142.729 & $0 \%$ \\
\hline & $\mathrm{z}$ & 508.368 & 508.368 & $0 \%$ \\
\hline
\end{tabular}

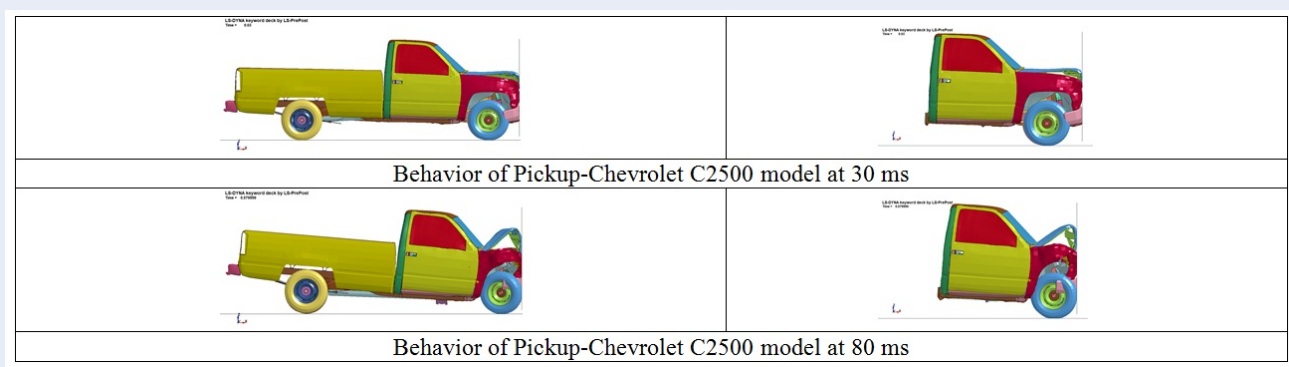

Figure 4: Deformation of Pickup-1994 Chevrolet C2500 at $30 \mathrm{~ms}$ and $80 \mathrm{~ms}$

of the modified models for this parameter are also excellent when they all follow the same trend and have nearly the same values as the full model and NCAP test 1741 .

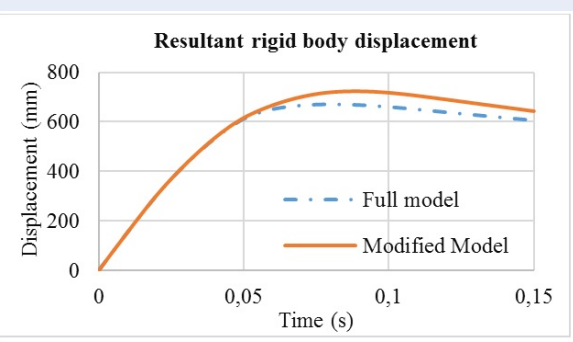

Figure 9: Comparison of resultant rigid body displacement for Pickup-1994 Chevrolet C2500

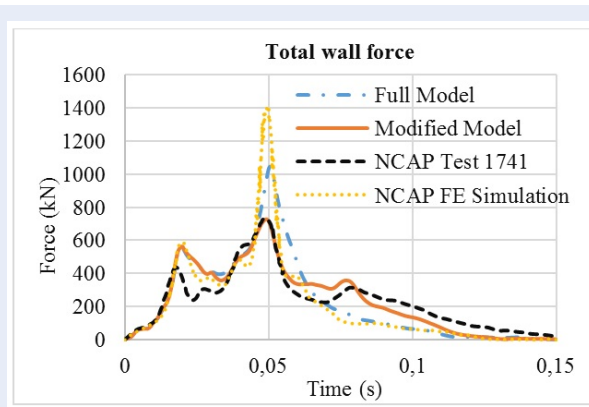

Figure 10: Comparison of total wall force for Pickup1994 Chevrolet C2500

The energy balance and the percentage error of total energy are shown in Figure 11 and Figure 12, respec- 
tively. The total kinetic energy and internal energy are lost due to non-physical energies. The average percentage error of total energy is $5.5 \%$.

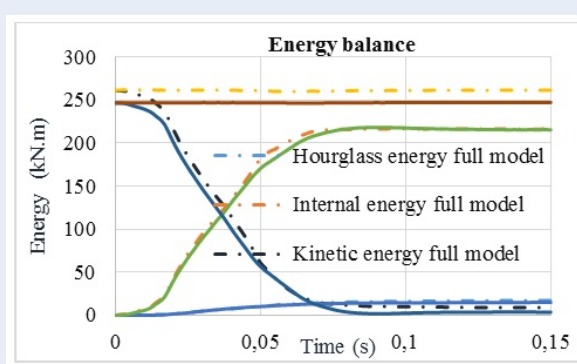

Figure 11: Comparison of energy balance for Pickup-1994 Chevrolet C2500

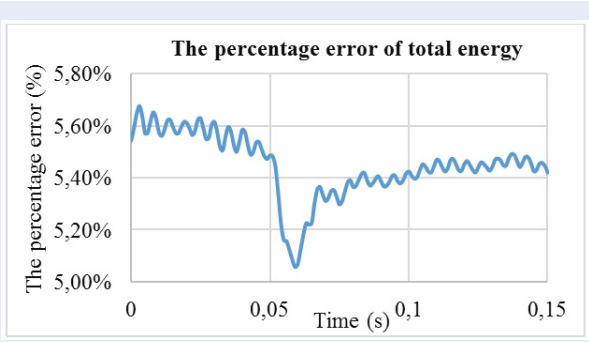

Figure 12: The percentage error of total energy for modified Pickup-1994 Chevrolet C2500

\section{SUV-1997 Toyota Rav 4}

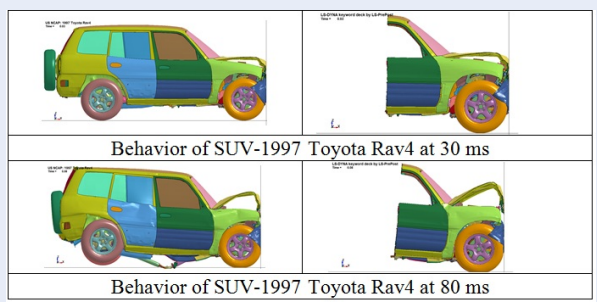

Figure 13: The behavior of SUV- 1997 Toyota Rav4 at $30 \mathrm{~ms}$ and $80 \mathrm{~ms}$.

Deformation of SUV-1997 Toyota Rav4 is described typically at $30 \mathrm{~ms}$ and $80 \mathrm{~ms}$ in Figure 13. The acceleration of engine top and engine bottom are shown in Figure 14 and Figure 15. Although there is small fluctuation but the tendency of all acceleration curves are similar. The acceleration curve of Modified model and Full model stick together.

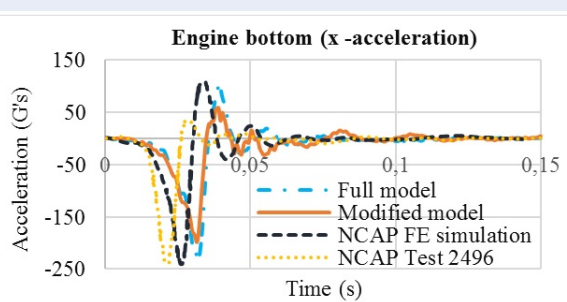

Figure 14: Comparison of engine bottom acceleration for SUV-1997 Toyota Rav 4

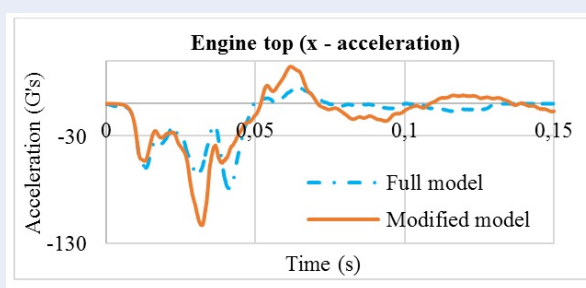

Figure 15: Comparison of engine top acceleration for SUV-1997 Toyota Rav 4

The velocity of engine bottom and engine top are shown in Figure 16 and Figure 17, respectively. They match very well.

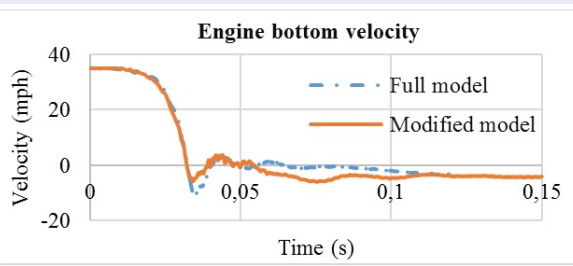

Figure 16: Comparison of engine bottom velocity for SUV-1997 Toyota Rav 4

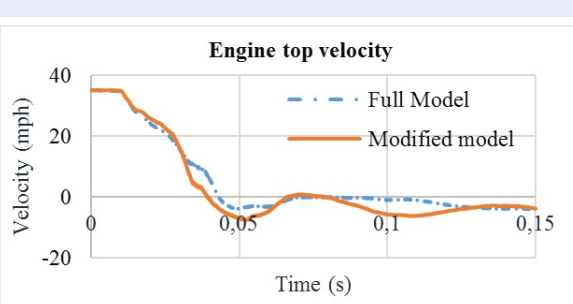

Figure 17: Comparison of engine top velocity for SUV-1997 Toyota Rav 4 
The total wall force and vehicle displacement are shown in Figure 18 and Figure 19. The curve of Full model and Modified model in Figure 18 stick together closer than others while Modified model curve is closer to NCAP test 2496 than others in Figure 19. The cause lies in the change of inertia.

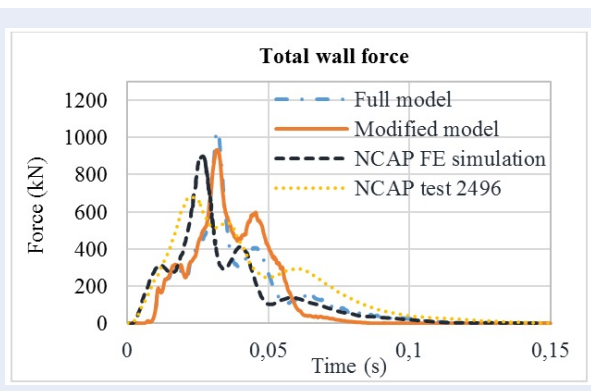

Figure 18: Comparison of wall force for SUV-1997 Toyota Rav 4

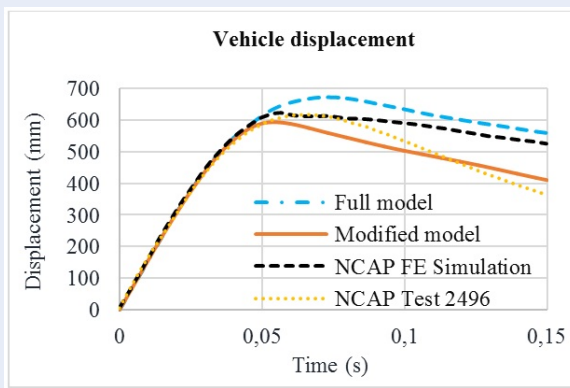

Figure 19: Comparison of vehicle displacement for SUV-1997 Toyota Rav 4

The energy balance and the percentage error of total energy are shown in Figure 20 and Figure 21, respectively. The energy balance graph show an excellent result. The average percentage error of total energy of modified model compare to full model is about $2 \%$.

\section{SUV-2002 Ford Explorer}

Deformation of SUV-2002 Ford Explorer is described typically at $30 \mathrm{~ms}$ and $80 \mathrm{~ms}$ in Figure 22. The acceleration of engine top and engine bottom are shown in Figure 23 and Figure 24. There are in good agreement. The acceleration curve of Modified model and Full model are matched well.

The total wall force and force-displacement are shown in Figure 25 and Figure 26, respectively. In both line graphs, the tendency of all curves are similar. In particular, the curve of Full model and Modified model stick together closer than others.

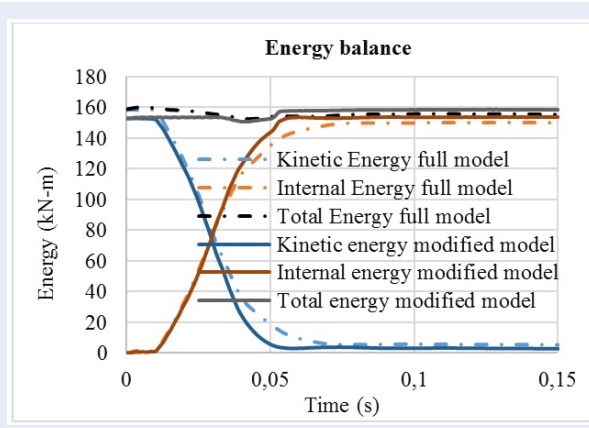

Figure 20: Comparison of energy balance for SUV1997 Toyota Rav 4

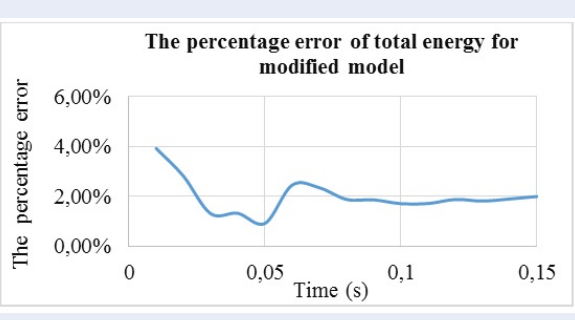

Figure 21: The percentage error of total energy for SUV-1997 Toyota Rav 4

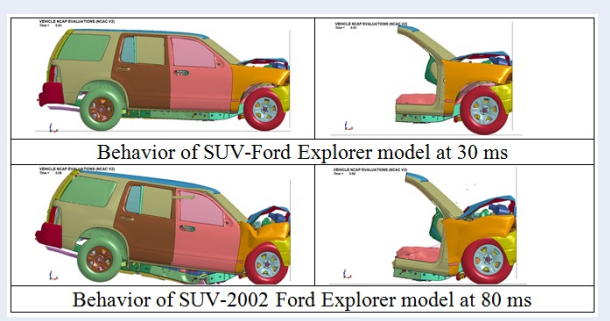

Figure 22: The behavior of SUV-2002 Ford Explorer at $30 \mathrm{~ms}$ and $80 \mathrm{~ms}$

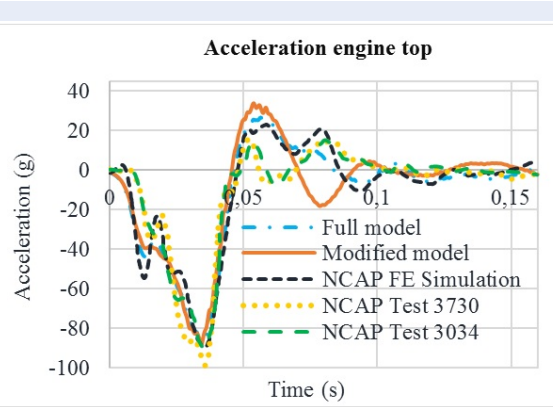

Figure 23: Comparison of engine top acceleration SUV-2002 Ford Explorer 


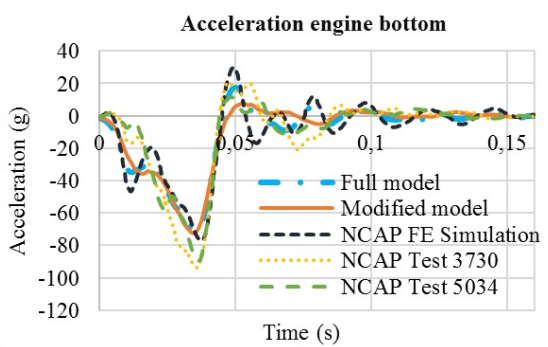

Figure 24: Comparison of engine bottom acceleration for SUV-2002 Ford Explorer

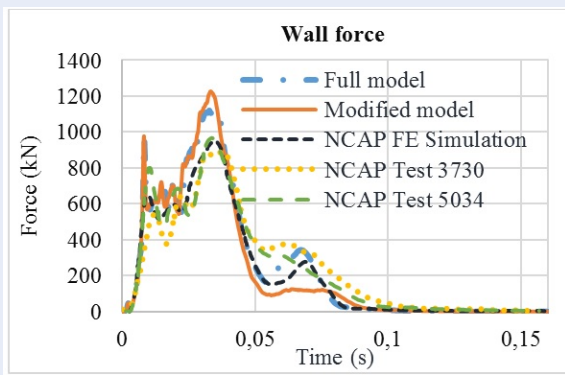

Figure 25: Comparison of wall force for SUV-2002 Ford Explorer

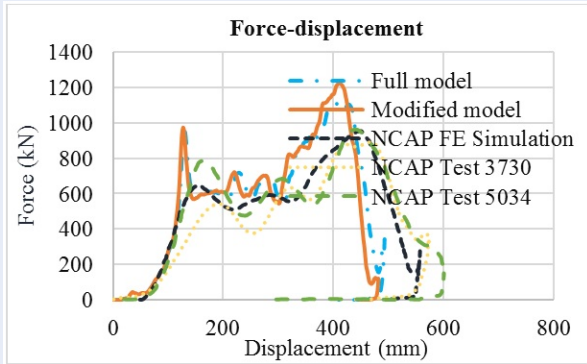

Figure 26: Comparison of force-displacement for SUV-2002 Ford Explorer

The velocity of engine top, engine bottom and rigid body displacement are illustrated from Figure 27 to Figure 29. They are in very good agreement. The energy balance and the percentage error of total energy are shown in Figure 30 and Figure 31, respectively. The energy curves stick together. The average percentage error of total energy of modified model compare to full model is $1 \%$.

\section{Sedan-2010 Toyota Yaris}

Deformation of Sedan-2010 Toyota Yaris is described typically at $30 \mathrm{~ms}$ and $80 \mathrm{~ms}$ in Figure 32 . The accel-

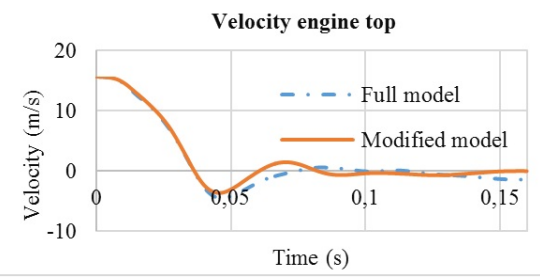

Figure 27: Comparison of engine top velocity for SUV-2002 Ford Explorer

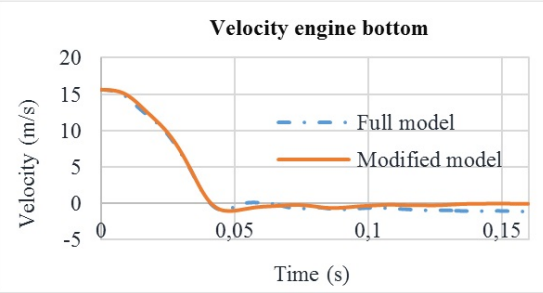

Figure 28: Comparison of engine bottom velocity for SUV-2002 Ford Explorer

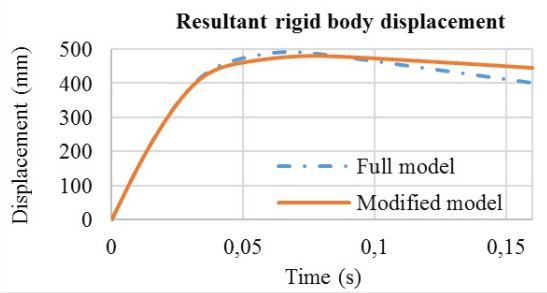

Figure 29: Comparison of resultant rigid body displacement for Explorer Ford

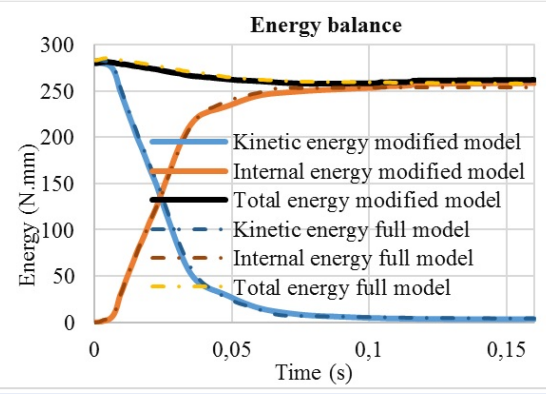

Figure 30: Comparison of energy balance for SUV2002 Ford Explorer 


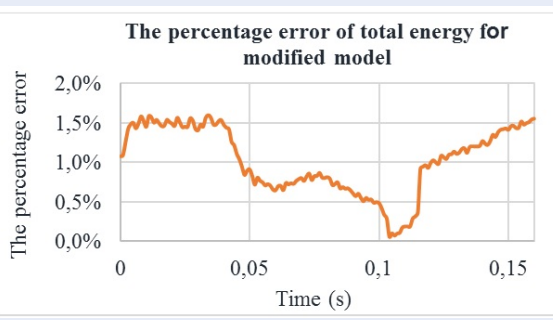

Figure 31: The verification graph of the modified SUV-2002 Ford Explorer

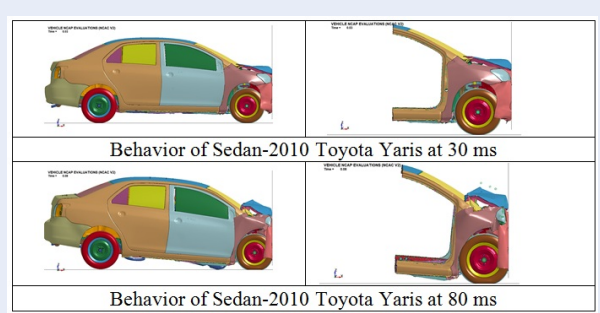

Figure 32: The behavior of Sedan-2010 Toyota Yaris at $30 \mathrm{~ms}$ and $80 \mathrm{~ms}$

eration of engine top and engine bottom are shown in Figure 33 and Figure 34. They have similar tendency. The acceleration curve of Modified model and Simulation SAE60 are in good agreement.

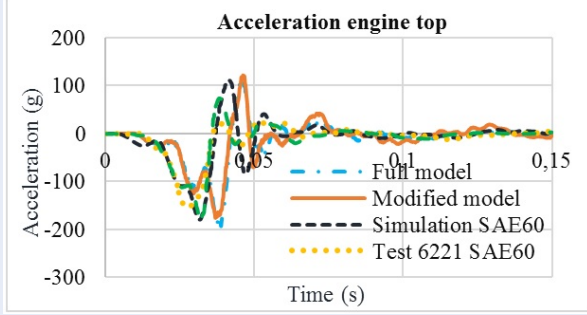

Figure 33: Comparison of engine top acceleration for Sedan-2010 Toyota Yaris

The total wall force and force-displacement are shown in Figure 35 and Figure 36, respectively. All curves have similar tendency in Figure 35, the Modified model and Full model curves have good agreement while the Modified model curve and the Simulation SAE60 stick closer than others in Figure 36.

In force-displacement graph, there are many discrepancies in the comparison between Full model and Modified model because the displacement obtained in this graph is resultant displacement and the displacement in the direction of the height and width of cars

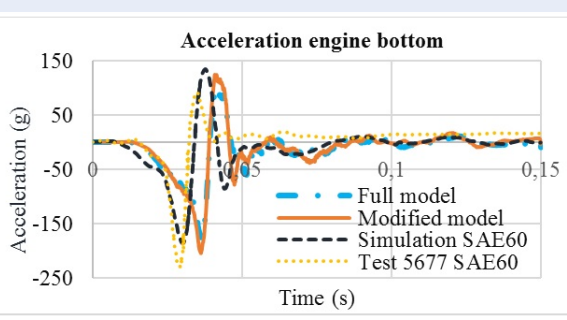

Figure 34: Comparison of engine bottom acceleration for Sedan-2010 Toyota Yaris

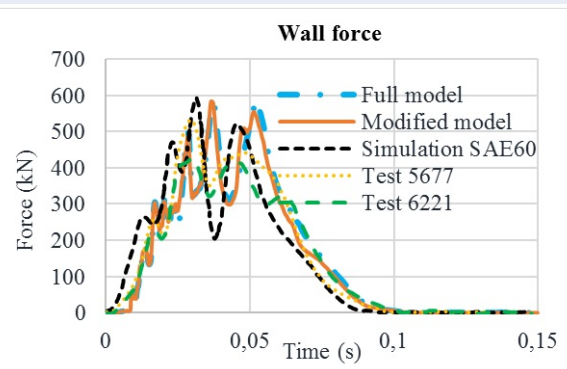

Figure 35: Comparison of wall force for Sedan-2010 Toyota Yaris

are significantly different from the full model. However, as the car moving in the longitudinal direction and this is a frontal crash test with nearly no rotation about the vertical axis, this inaccuracy has only a little effect on the final results and can be neglected.

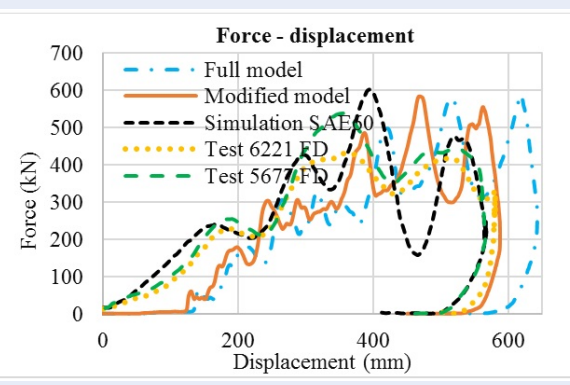

Figure 36: Comparison of force-displacement for Sedan-2010 Toyota Yaris

The velocity of engine top, engine bottom and rigid body displacement are presented from Figure 37 to Figure 39. They matched very well.

The energy balance and the percentage error of total energy are shown in Figure 40 and Figure 41, respectively. The energy balance graph show an excellent result. The average percentage error of total energy of 


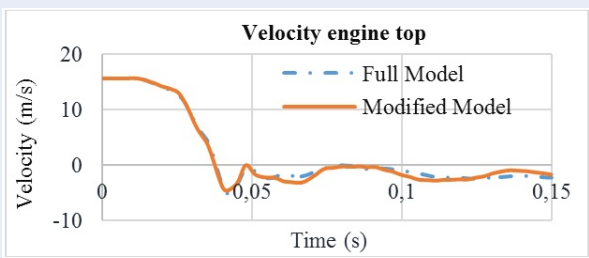

Figure 37: Comparison of engine top velocity for Sedan-2010 Toyota Yaris

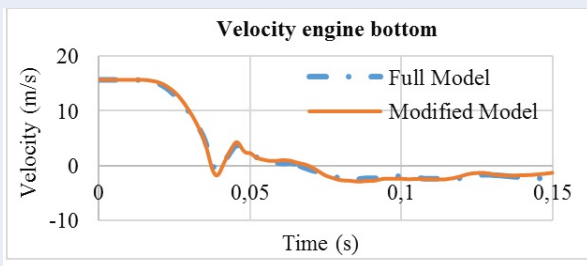

Figure 38: Comparison of engine bottom velocity for Sedan-2010 Toyota Yaris

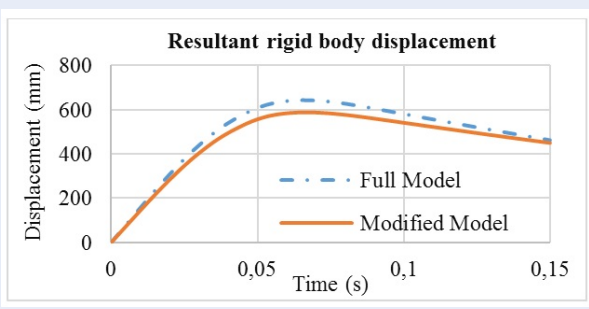

Figure 39: Comparison of resultant rigid body displacement for Sedan-2010 Toyota Yaris

modified model compare to full model is about $3.5 \%$.

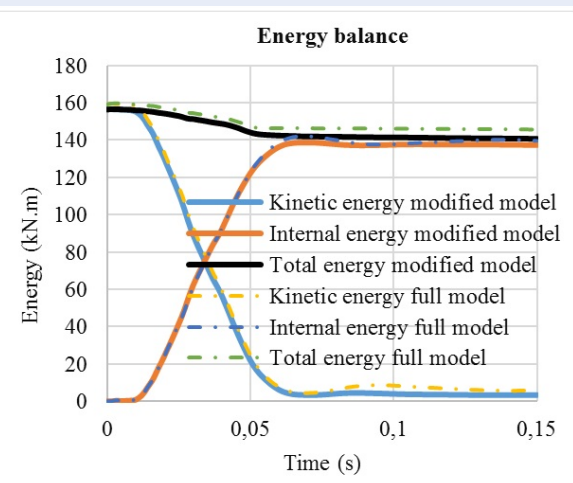

Figure 40: Comparison of energy balance for Sedan-2010 Toyota Yaris

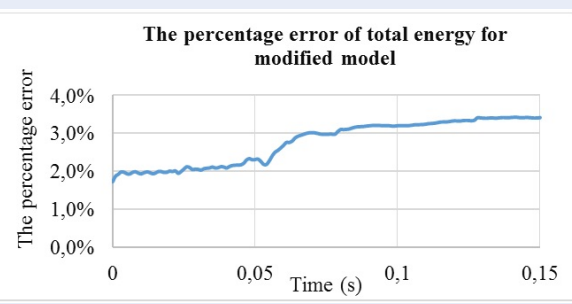

Figure 41: The percentage error of total energy for Sedan-2010 Toyota Yaris

\section{Sedan-2012 Toyota Camry}

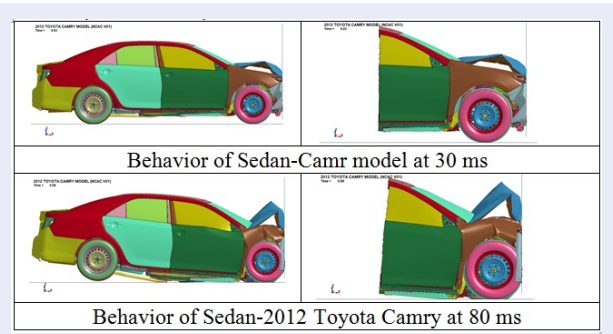

Figure 42: The behavior of Sedan-2012 Toyota Camry at $20 \mathrm{~ms}$ and $60 \mathrm{~ms}$

Deformation of Sedan-2012 Toyota Camry is described typically at $30 \mathrm{~ms}$ and $80 \mathrm{~ms}$ in Figure 42. The acceleration of engine top and engine bottom are shown in Figure 43 and Figure 44. The acceleration curve of Modified model and Full model stick together. There is small difference between NCAP Test with the two others but insignificant in case of Engine top acceleration, Figure 43. In general, they are matched very well.

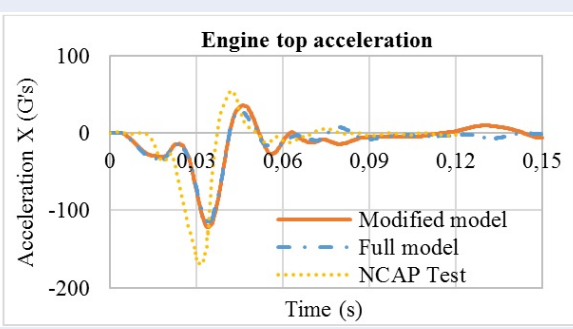

Figure 43: Comparison of engine top acceleration for Sedan-2012 Toyota Camry

Vehicle displacement, Total wall force and Forcedisplacement are shown from Figure 45 to Figure 47. The curve of Full model and Modified model show an excellent agreement. 


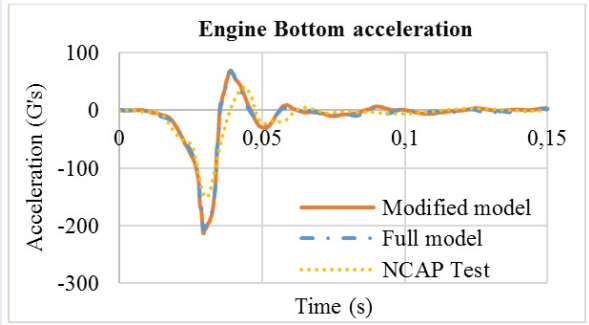

Figure 44: Comparison of engine bottom acceleration for Sedan-2012 Toyota Camry

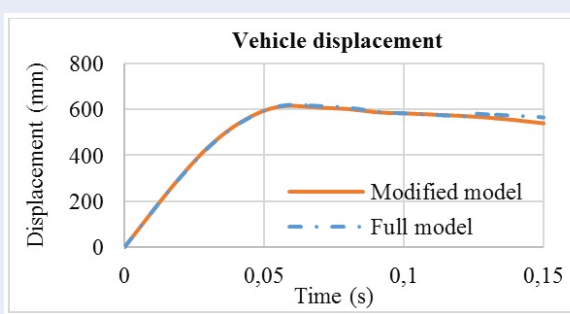

Figure 45: Comparison of vehicle displacement for Sedan-2012 Toyota Camry

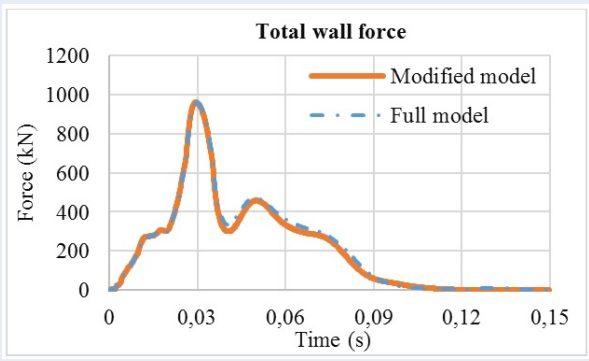

Figure 46: Comparison of wall force for Sedan-2012 Toyota Camry

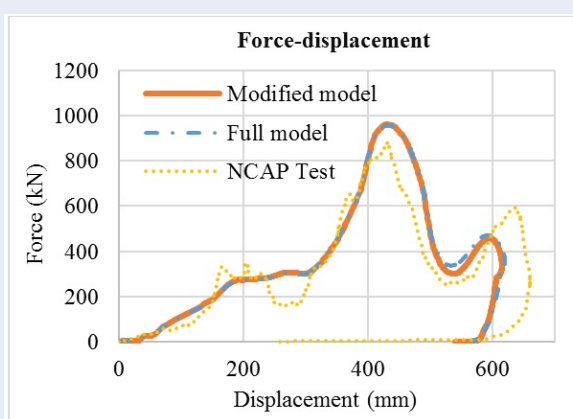

Figure 47: Comparison of force-displacement for Sedan-2012 Toyota Camry
The energy balance and the percentage error of total energy are shown in Figure 48 and Figure 49, respectively. The energy balance graph shows an excellent result. The average percentage error of total energy of modified model compare to full model is $4.8 \%$

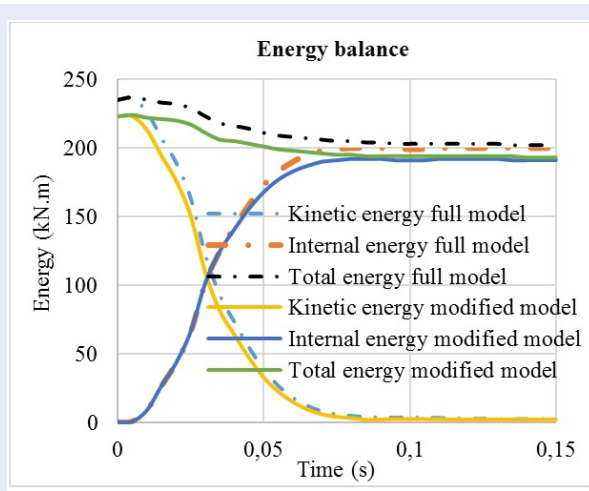

Figure 48: Comparison of energy balance for Sedan-2012 Toyota Camry

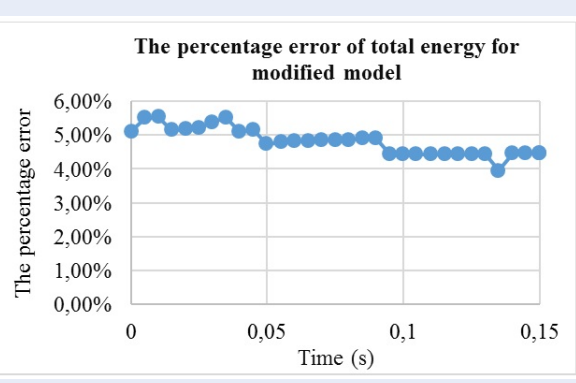

Figure 49: The percentage error of total energy for modified Sedan-2012 Toyota Camry

\section{Sedan-1996 Dodge Neon}

Deformation of Sedan-1996 Dodge Neon is described typically at $30 \mathrm{~ms}$ and $80 \mathrm{~ms}$ in Figure 50 . The acceleration of engine top and engine bottom are shown in Figure 51 and Figure 52. Modified model curve and Full model curve show good agreement. There are small differences when compare to NCAP test.

Vehicle displacement, Total wall force and Forcedisplacement are shown from Figure 53 to Figure 55 for Neon model. The same result found here, the excellent tend between Modified model and Full model. The energy balance and the percentage error of total energy are shown in Figure 56 and Figure 57, respectively. The energy balance graph shows an excellent agreement. The average percentage error of total energy of modified model compare to full model is $4 \%$. 


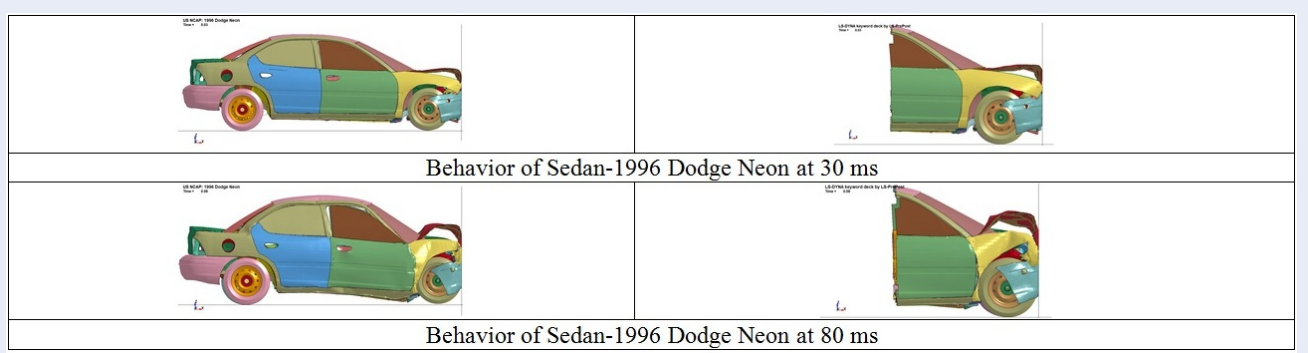

Figure 50: The behavior of Sedan-1996 Dodge Neon at 20ms and 60ms.

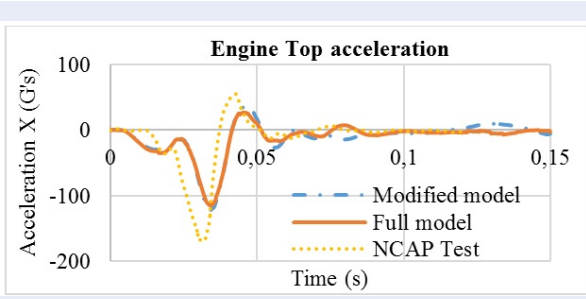

Figure 51: Comparison of engine top acceleration for Sedan-1996 Dodge Neon

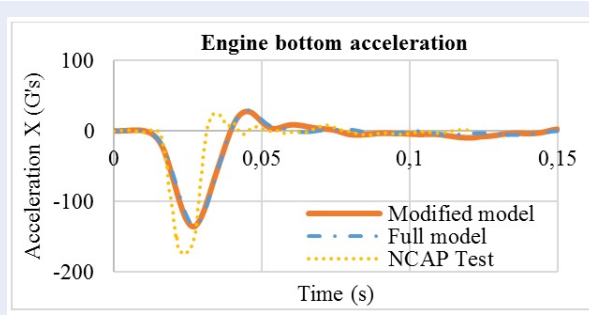

Figure 52: Comparison of engine bottom acceleration for Sedan-1996 Dodge Neon

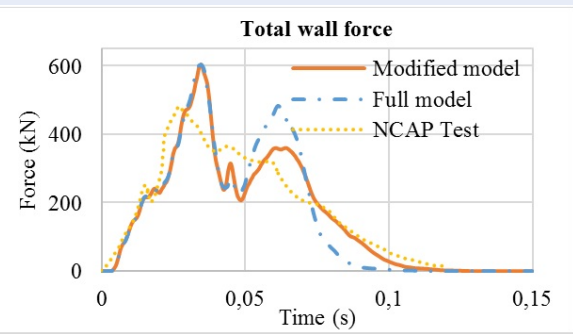

Figure 53: Comparison of wall force for Sedan-1996 Dodge Neon

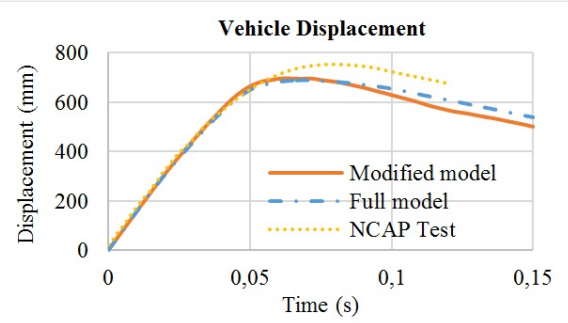

Figure 54: Comparison of vehicle displacement for Sedan-1996 Dodge Neon

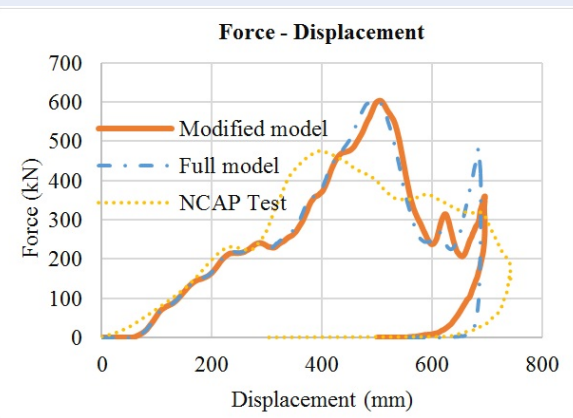

Figure 55: Comparison of force-displacement for Sedan-1996 Dodge Neon

\section{Findig the reduction of simulation time}

Modified models gives a good results when reducing a large amount of resources used in computational simulation.

\section{Pickup-1994 Chevrolet C2500}

The Elapsed time decrease $0.22 \%$ when run with modified model. Detail of the results is described in Table 7 . 


\section{Table 7: The source comparison of Pickup model}

\begin{tabular}{lll}
\hline & Full model & Modified model \\
LS-DYNA Version & smp s R7.0.0 & smp s R7.0.0 \\
Revision & 79055 & 79055 \\
Platform & WINDOWS X64 & WINDOWS X64 \\
OS Level & Windows XP/Vista/7 SRV 2003/2008 & Windows XP/Vista/7 SRV 2003/2008 \\
Number of CPU's & 8 & 8 \\
Elapsed time & 1 hours 41 min. 22 sec. & 1 hours 18 min. 56 sec. \\
\hline
\end{tabular}

Table 8: The source comparison of Toyota Rav4 model

\begin{tabular}{lll}
\hline & Full model & Modified model \\
LS-DYNA Version & smp s R11.0.0 & smp s R7.0.0 \\
Revision & 129956 & 79055 \\
Platform & WINDOWS X64 (SSE2) & WINDOWS X64 \\
OS Level & Windows XP/Vista/7 SRV 2003/2008 & Windows XP/Vista/7 SRV 2003/2008 \\
Number of CPU's & 8 & 8 \\
Elapsed time & 8 hours 17 minutes. & 2 hours 34 minutes 22 seconds. \\
\hline
\end{tabular}

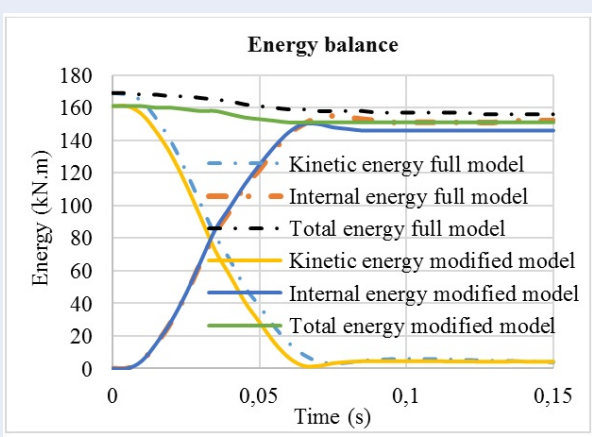

Figure 56: Comparison of energy balance for Sedan-1996 Dodge Neon

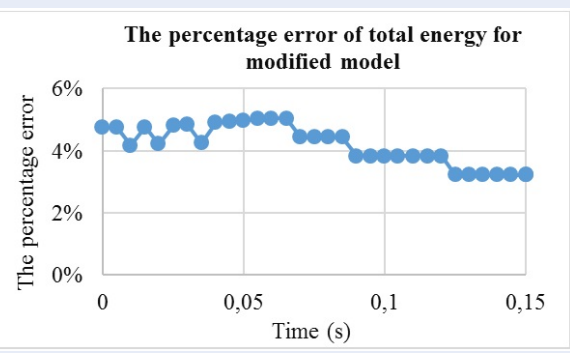

Figure 57: The percentage error of total energy for modified Sedan-1996 Dodge Neon

\section{SUV-1997 Toyota Rav4}

The Elapsed time decrease $69 \%$ when run with modified model. Detail of the results is described in Table 8 .

\section{SUV-2002 Ford Explorer}

The Elapsed time decrease $28 \%$ when run with modified model. Detail of the results is described in Table 9.

\section{Sedan-2010 Toyota Yaris}

The Elapsed time decrease $58 \%$ when run with modified model. Detail of the results is described in Table 10.

\section{Sedan-2012 Toyota Camry}

The Elapsed time decrease $62 \%$ when run with modified model. Detail of the results is described in Table 11 .

\section{Sedan-1996 Dodge Neon}

The Elapsed time decrease $37 \%$ when run with modified model. Detail of the results is described in Table 12 .

\section{CONCLUSION}

The results show that the FE models of vehicle front structures can replace original models in a frontal crash to reduce time operation and memory resources significantly. Conservation of vehicle front structures' CG makes sure that the results of the modified 
Table 9: The source comparison of Ford Explorer model

\begin{tabular}{lll}
\hline & Full model & Modified model \\
LS-DYNA Version & smp s R7.0.0 & smp s R7.0.0 \\
Revision & 79055 & 79055 \\
Platform & WINDOWS X64 & WINDOWS X64 \\
OS Level & Windows XP/Vista/7 SRV 2003/2008 & Windows XP/Vista/7 SRV 2003/2008 \\
Number of CPU's & 8 & 8 \\
Elapsed time & 8 hours $11 \mathrm{~min} .13 \mathrm{sec}$. & 5 hours 53 min. $22 \mathrm{sec}$. \\
\hline
\end{tabular}

Table 10: The source comparison of Yaris sedan model

\begin{tabular}{|c|c|c|c|}
\hline & Full model & & Modified model \\
\hline LS-DYNA Version & smp s R7.0.0 & & smp s R7.0.0 \\
\hline Revision & 79055 & & 79055 \\
\hline Platform & WINDOWS X64 & & WINDOWS X64 \\
\hline OS Level & $\begin{array}{ll}\text { Windows } & \text { XP/Vista/7 } \\
\text { 2003/2008 } & \end{array}$ & SRV & Windows XP/Vista/7 SRV 2003/2008 \\
\hline Number of CPU's & 8 & & 8 \\
\hline Elapsed time & 17 hours $2 \mathrm{~min} .11 \mathrm{sec}$. & & 7 hours $6 \mathrm{~min} .27 \mathrm{sec}$ \\
\hline
\end{tabular}

Table 11: The source comparison of Camry sedan model

\begin{tabular}{lll}
\hline & Full model & Modified model \\
LS-DYNA Version & smp s R11.0.0 & smp s R7.0.0 \\
Revision & 129956 & 79055 \\
Platform & WINDOWS X64 (SSE2) & WINDOWS X64 \\
OS Level & Windows 7/8/10 \& Srv 2008/2012 R2 & Windows XP/Vista/7 SRV 2003/2008 \\
Number of CPU's & 8 & 8 \\
Elapsed time & 21 hours 44 minutes 6 seconds. & 8 hours 20 minutes 6 seconds. \\
\hline
\end{tabular}

Table 12: The source comparison of Neon model

\begin{tabular}{lll}
\hline & Full model & Modified model \\
LS-DYNA Version & smp s R11.0.0 & smp s R7.0.0 \\
Revision & 129956 & 79055 \\
Platform & WINDOWS X64 (SSE2) & WINDOWS X64 \\
OS Level & Windows 7/8/10 \& Srv 2008/2012 R2 & Windows XP/Vista/7 SRV 2003/2008 \\
Number of CPU's & 8 & 8 \\
Elapsed time & 3 hours 36 minutes 59 seconds. & 2 hours 15 minutes 58 seconds. \\
\hline
\end{tabular}


vehicles similar to original vehicles in front crash with high accuracy.

\section{ACKNOWLEDGEMENT}

Numerical simulation in this paper is conducted in High Performance Computing Laboratory (HPC Lab), Faculty of Computer Science \& Engineering, Ho Chi Minh City University of Technology - HCMUT, Vietnam National University - VNU.

\section{LIST OF ABBREVIATIONS}

FEM: Finite Element Method.

FE: Finite Element

C.G: Center of gravity.

CNRB: Nodal Rigid Body constraints

NCAC: National Crash Analysis Center

NCAP: New Car Assessment Program

NHTSA: National Highway Traffic Safety Administration

O: Original model

M: Modified model

\section{COMPETING INTERESTS}

The authors pledge that there are no conflicts of interest in the publication of the paper.

\section{AUTHORS' CONTRIBUTION}

Hung Anh Ly takes responsibility as principal investigator, brainstorming ideas for writing articles and reviewing articles; Orientation, evaluation and interpretation of simulation results.
Phu Thuong Luu Nguyen has participated in data analysis and evaluation results.

Thien Phu Nguyen has participated in simplifying original FEM vehicle models and set up crash simulation, supporting writing articles.

Dinh Nhat Tran has participated in running simulations, analyzing results and verifying results, supporting writing articles.

\section{REFERENCES}

1. Stein $M$, et al. Unified parametric car model - A simplified model for frontal crash safety. LS-DYNA Forum, Ulm. 2012;.

2. Liu Y. Development of simplified models for crashworthiness analysis. Doctoral Dissertation. 2005;.

3. Al-Thairy $H$, Wang YC. Simplified FE vehicle model for assessing the vulnerability of axially compressed steel columns against vehicle frontal impact," Journal of Constructional Steel Research. 2014;p. 190 -203. Available from: https://doi.org/10. 1016/j.jcsr.2014.07.005.

4. FEA Information Inc. News \& Technical Information. 2002;2(1). Available from: https://www.dynalook.com/fea-newsletters/ fea-newsletters-2002/fea-newsletter-january-2002.pdf.

5. Finite Element Model of C2500 Pickup Truck (Model year 1994), FHWA/NHTSA National Crash Analysis Center. 1994;.

6. Finite Element Model of Toyota Rav 4 (Model year 1997), FHWA/NHTSA National Crash Analysis Center. 1997;

7. Marzougui D, Samaha RR, Tahan F, Cui C, Kan CD. Extended Validation of the Finite Element Model for the 2002 Ford Explorer Sport Utility Vehicle, National Crash Analysis Center. 2012;

8. Marzougui D, Samaha RR, Tahan F, Cui C, Kan CD. Extended Validation of the Finite Element Model for the 2010 Toyota Yaris Passenger Sedan, National Crash Analysis Center. 2012;.

9. 2012 Toyota Camry Finite Element Model Verson 1, FHWA/NHTSA National Crash Analysis Center.;

10. Finite Element Model of Dodge Neon, Model Year 1996, FHWA/NHTSA National Crash Analysis Center; 


\title{
Xây dựng mô hình phần tử hữu hạn của xe ô tô bằng cách đơn giản hóa mô hình nguyên mẫu
}

\author{
Lý Hùng Anh ${ }^{1,2, *}$, Nguyễn Phụ Thượng Lưu ${ }^{3}$, Trần Đình Nhật ${ }^{1,2}$, Nguyễn Thiên Phú ${ }^{1,2}$
}

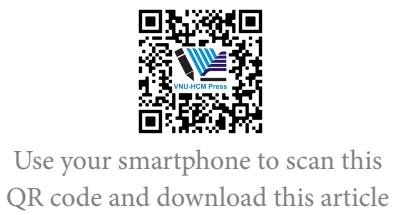

${ }^{1}$ Khoa Kỹ thuật Giao thông, Trường Đại học Bách khoa

${ }^{2}$ Đại học Quốc gia Thành phố Hồ Chí Minh

${ }^{3}$ Bộ môn Công nghệ Ô tô, Trường Đại học Công nghệ Thành phố Hồ Chí Minh

Liên hệ

Lý Hùng Anh, Khoa Kỹ thuật Giao thông, Trường Đại học Bách khoa

Đại học Quốc gia Thành phố Hồ Chí Minh

Email: lyhunganh@hcmut.edu.vn

Lịch sử

- Ngày nhận: 27-10-2020

- Ngày chấp nhận: 03-3-2021

- Ngày đăng: 15-3-2021

DOI : 10.32508/stdjet.v4i1.782

\section{Check for updates}

\section{Bản quyền}

๑ ĐHQG Tp.HCM. Đây là bài báo công bố mở được phát hành theo các điều khoản của the Creative Commons Attribution 4.0 International license.

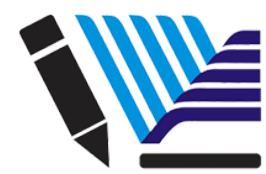

VNU-HCM Press

\section{TÓM TẮT}

Phương pháp nghiên cứu thực ng hiệm trong va chạm xe ô tô thường tiêu tốn rất nhiều chi phí. Do đó, phương pháp mô phỏng trong các nghiên cứu này bằng cách sử dụng mô phỏng số được ứng dụng rộng rãi. Tuy nhiên, các mô hình ô tô nguyên gốc được cung cấp bởi National Crash Analysis Center (NCAP) chứa rất nhiêu bô phân có cấu trúc phức tap̣, đăc biêt là phần sau của các mô hình ô tô không góp phần vào ứng xử va chạm trực diện mà thông thường đùng để đánh giá mức độ chấn thương của người đi bộ hoặc người đi xe máy. Đặc biệt là phần phía sau của xe không có ảnh hưởng lớn đến ứng xử của mô hình cần khảo sát như là người đi bộ hoặc người đi xe máy trong va chạm trực diện. Để tiết kiệm thời gian và nguồn tài nguyên, việc đơn giản hóa các mô hình xe ô tô để dùng trong nghiên cứu mô phỏng là điều cần thiết với mục tiêu là giảm xấp xỉ $50 \%$ tổng số nút và phần tử của mỗi mô hình. Mục đích của bài nghiên cứu này là xây dựng các mô hình phần tử hữu hạn xe ô tô mới dựa trên các mô hình nguyên mẫu và các mô hình xe mới này phải được duy trì các giá trị quan trọng như khối lượng và vị trí trọng tâm. Đối với sự sai khác về mô men quán tính gây ra một ảnh hưởng rõ ràng dần đến sai khác so với mô hình gốc tuy nhiên điều này có thể bỏ qua được bằng cách đặt điều kiện biên vào mô hình xe đã đơn giản hóa. Những mô hình phần tử hữu hạn xe ô tô ban đầu được phát triển bằng LS-DYNA và được xác minh, đánh giá với kết quả nghiên cứu thực nghiệm. Các mô hình xe phần tử hữu hạn đã được đơn giản hóa sẽ được xác minh bằng cách so sánh, đánh giá với dữ liệu thực nghiệm và mô phỏng được cung cấp bởi NCAP cũng như là kết quả mô phỏng của mô hình phần tử hứu hạn ban đầu. Có 6 mô hình xe được xây dựng lại trong nghiên cứu này cụ thể là 1 mô hình xe Pickup, 2 mô hình xe SUV và 3 mô hình xe Sedan. Bởi vì mô hình xe ô tô không phải là đối tượng chính để quan tâm đánh giá trong va chạm nên năng lượng và ứng xử động học của phần trước ở các mô hình xe thu gọn giữ một vai trò quan trong cần phải kiểm chứng. Kết quả đạt được là sáu mô hình phần tử hữu hạn xe ô tô đã được sửa đổi đơn giản hóa cho kết quả mô phỏng hợp lý và giảm đáng kể số nút và phần tử, điều này có nghĩa là thời gian mô phỏng đã giảm đi khá nhiều. Các mô hình phần tử hữu hạn xe ô tô mới này sẽ được ứng dụng vào các nghiên cứu mô phỏng va chạm trực diện sắp tới.

Từ khoá: Mô hình phần tử hữu hạn, nội năng, an toàn trong va chạm, đơn giản hóa mô hình xe, tối ưu hóa phần trước của xe
Trích dẫn bài báo này: Anh $L$ H, Lưu N P T, Nhật $T \mathrm{D}$, Phú $\mathrm{N} T$. Xây dựng mô hình phần tử hữu hạn của xe ô tô bằng cách đơn giản hóa mô hình nguyên mẫu. Sci. Tech. Dev. J. - Eng. Tech.; 4(1):680-696. 